\title{
XXXII. On some remarleable Sepulchral objects from Italy, Styria, and
} Mecklenburgh. By JoHN MitcheLL Kemble.

Read December 13, 1855 .

I AM anxious to direct attention to certain very remarkable figures and combinations of figures, the most of which have been found in interments, in various parts of Europe, in the hope that notice of them may induce some member of the Society of Antiquaries to pursue their history further than I can do. It lies somewhat beyond the strict limits which I am compelled to put to my studies, and deserves a more exclusive treatment than $I$ have time to bestow upon it: but it seems a subject likely to repay a careful investigation.

Some years ago, namely in 1843, a large but somewhat flat tumulus was opened at Peccatel, a village not very far from the town of Schwerin. In it were found - together with a sword, a knife, and other articles of bronze, and a gracefullyformed twisted armlet of gold - the four wheels and axles, with curved axletrees, of a bronze waggon of diminutive size. The account of this discovery, which is recorded in the Ninth Yearly Report of the Historical and Antiquarian Society of Schwerin (p. 369, etc.) when divested of redundant and irrelevant matter, is as follows :-

In the year mentioned, a golden bracelet was offered for sale to the Society, with the statement that it had been found by a peasant while digging for stones on the south side of a barrow at Peccatel. On inquiry the finder stated that he had also found bits of copper, which he still possessed, with the exception of two wheels of copper : these he had given a neighbouring blacksmith in exchange for some iron nails. The first steps taken were to prohibit any further excavation, to recover the bartered wheels, and the rest of the bits of copper, and to survey the barrow. It was found of sufficient importance to be opened by the Society, and the grand ducal family, male and female, honoured the excavation with their presence. This was carefully and skilfully conducted by that accomplished barrow. digger Archivar Dr. Lisch, and the then court-painter Schumacher, to whose 
hand we owe the excellent drawings which accompany the report. The barrow was the middle one of three, one being larger, one smaller: it had a diameter of about fifty paces, and a perpendicular height of five feet. The smallest barrow, which was opened upon the same occasion, offered no results at all. The largest, concerning which a number of strange traditions were current among the villagers, was left untouched at the time, but has since been explored, and proved to be most remarkable; with it, however, we have nothing to do at present.

The barrow which was to be investigated was surrounded by a perfect ring or wall of closely packed stones, of middling size, that is, as my own experience teaches, about the size of our old paving stones. It was, as is also generally the case with the North German tumuli, invisible: that is to say, completely covered with earth and turf at the base of the barrow. This was pronounced by the labourers employed to consist of earth brought from some distance, and was not at all events of the same material as the surrounding plain. Within this earth were three vaults, as Lisch calls them, by which, however, he means rather stone-heaps or cairns, as we name them. Two stood together, very near the centre of the barrow, running nearly north and south, and were united by a sort of dam, an arrangement, by the bye, which I once found in a barrow at Armelingen, in the heathdistrict of Soltau: they were 6 feet long, 4 wide, and 4 high. The third lay in the southern edge of the barrow, in the direction from east to west, and before it was broken into had been 16 feet long and 10 wide. The man who had dug out the stones reported that it had been about 3 feet high. These cairns were all most carefully investigated. We begin with the largest. This had still a regular pavement of stones, laid upon the natural ground, which was thickly strewn with ashes and charcoal. Upon it had been found:-

1. The large vessel of bronze, represented Plate XXVI. fig. 1. It is of hammered metal, repoussé with several rows of small knobs, and had originally four twisted handles. It has a greatest diameter of $\mathbf{1 5}$ inches, and a height of about 7.

2. A cylinder of bronze with four feet; it is of the same workmanship as the vase, only a rather thicker metal (fig. 2 ). Its diameter is a little more than 3 inches, its height with the feet 6.

3. The waggon, as represented in fig. 3. This has bent axletrees forming a kind of yoke athwart the beam, and from the fragments we may believe that similar bent rods or yokes ran lengthwise, and connected the two axletrees together. This appears also from the rivets by which the several portions have been fastened together. And from another fragment equally riveted upon the same spot, it seems nearly certain that the feet of the cylinder were fixed at these 
Fin. 16
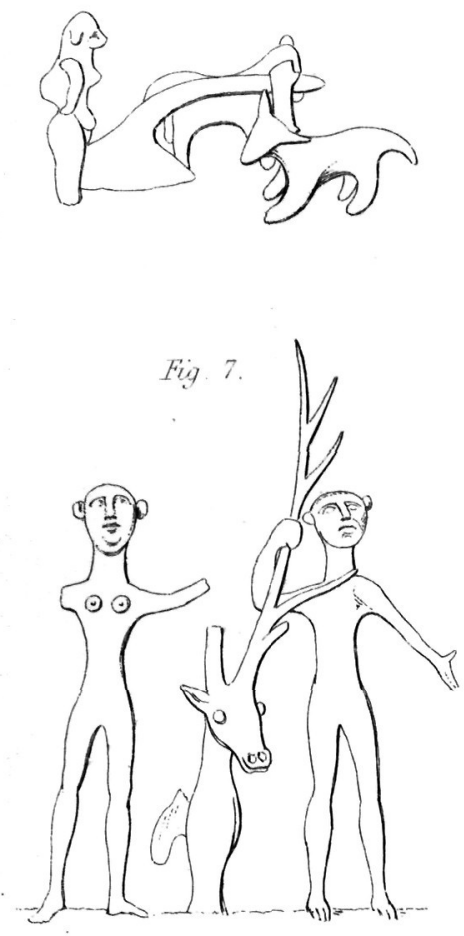

Fid. 11 .
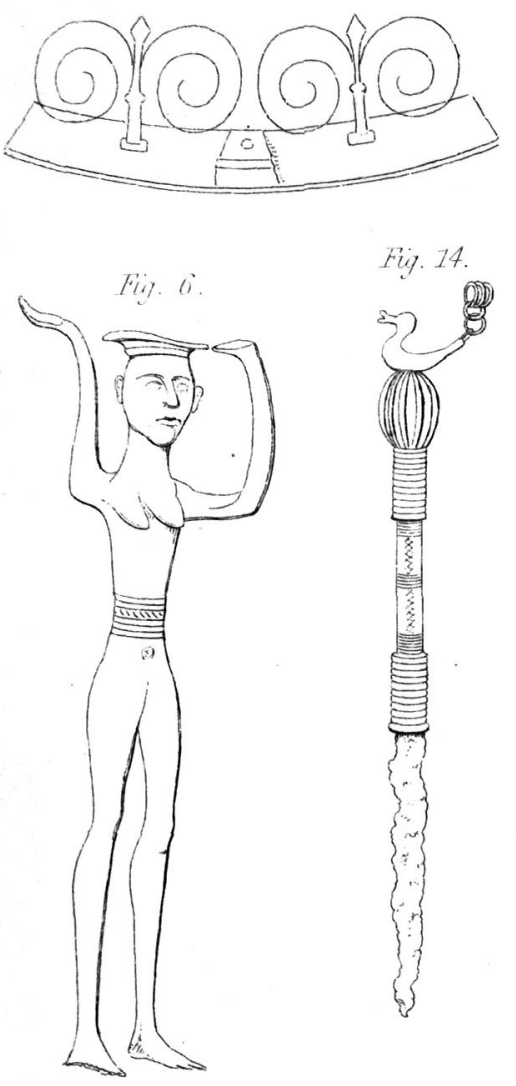

Fiif. 9
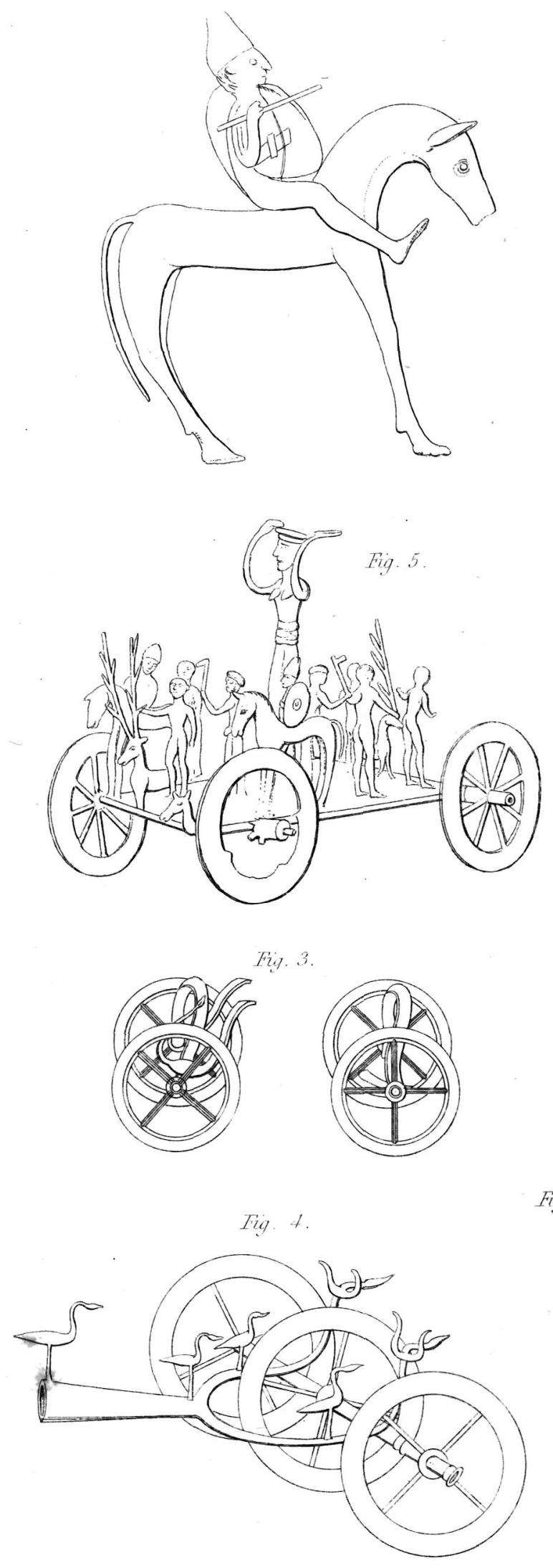

Fig. 15

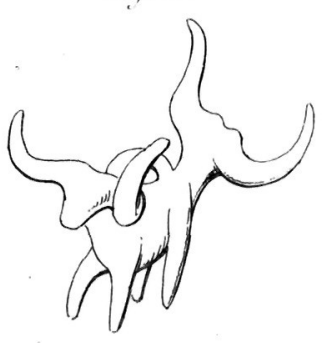

Fig. 8

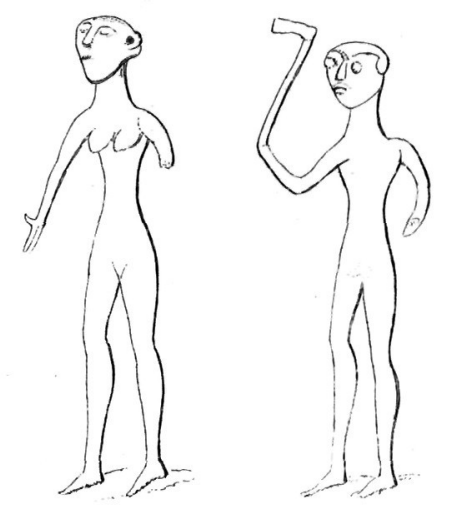

Fig. 1 .

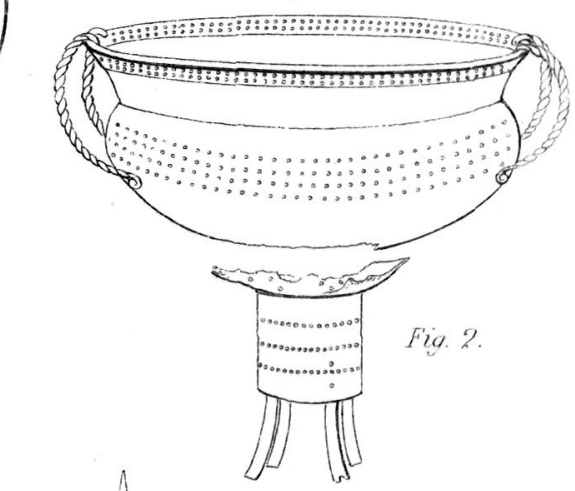

Fir. 12.

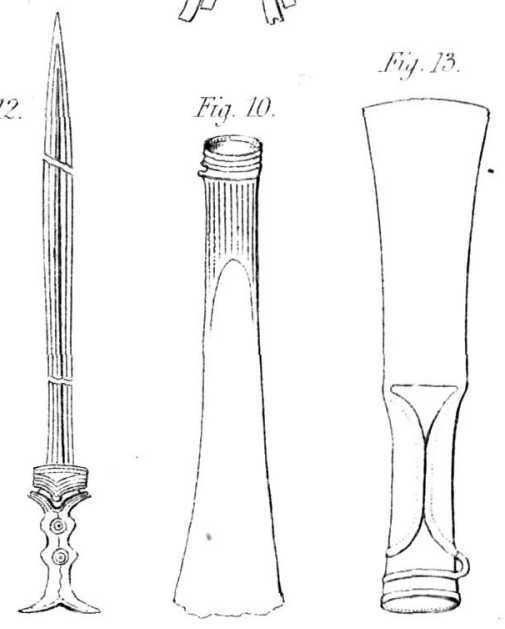

SEPULCHRAL OBIECTS FROM ITAIY \& GERMANY. 
Lour points. If this were so, the cylinder stood just over the bent rods and yokes; and, as upon the top of the cylinder a portion of a bronze vessel is riveted, which answers as nearly as can now be expected to the missing bottom of the rase, there can be little doubt that the three several parts were combined together, and that the waggon carried both vase and cylinder. In its present dilapidated and oxydated state, it could not do so, but it may be supposed to have been originally firm enough, if, as is probable, the bottom of the cylinder rested on the arched rods themselves. The wheels are four-spoked, and have evidently been cast, not hammered like the vase and cylinder. It is probable that the side rods had been bent upwards at each end of the waggon alike, in the manner in which one still remains. The manner in which these several portions were described to have lain under the stones renders it nearly certain that they were connected in the way described. The man who found them stated that the "kettle" stood at the eastern end of the heap; that the cylinder with its feet was in it, and the wheels \&c. under it, all crushed together by the weight of the stones.

4. The fourth object found was a sword of bronze, of the usual leaf-shape, rather more than two feet long, which had been broken into four pieces before it was deposited. The handle and pummel are, as far as I know, perfectly unique, although they bear a general resemblance in some details to other bronze swords found upon the continent. The pommel, which is hollow, is filled with the wood of the ash. The strig or tang is divided off by oval plates, obviously intended to compress leather, ivory, or whatever material may have been selected to clothe the hilt.

5. A knife of bronze, with a handle of the same metal, opened for the insertion of the material of the handle, and with a square knob to compress the same.

6. The armlet of gold of which mention has been made. The metal contains nearly ten per cent. of silver, which seems to be rather a larger proportion than can be accounted for by mere imperfection of separating the metals.

7. A kelt of bronze, of a form very unusual in the North of Germany; it is socketed and looped, but the opening is rather square than round, and the ornamentation reminds one a little of Irish and English specimens of the flat or simple form.

All these objects had been found at the first excavation. The following now also came to light.

8. An arrow-head of bronze, with barbs. 
9. The bronze blade of a small knife, four inches long, without a handle, and in three pieces, with original fracture.

In this interment there was not even a trace of earthen vessels; nor do I find any notice either of bones or other animal deposit. As these are the objects with which I have to deal, we will pass rapidly over the contents of the remaining two cairns. The most westerly of these contained, besides a small square piece of thin bronze plate, much injured by fire, a very interesting object which may possibly have been a belt, or even part of a defensive armour. It consists of leather, upon which bronze studs of different sizes have been fixed, and is sufficiently massive to resist even a sharp spear. Similar studs have been found in graves of the Lüneburg district by Lieut.-Gen. Count Münster, Baron v. Estorff, and myself.

The eastern cairn, which lay about five feet from the western one, contained, dispersed among the stones-

1. An urn of clay of very common form, without any ornament.

2. A long bronze pin, richly ornamented.

3. A brooch of bronze, with spiral plates, of the usual character.

4. A finger-ring of bronze, in which the bone still lay.

In the neighbourhood of this heap lay unburnt bones of a skull, scattered disorderly. But at the north end of the western cairn was a small rude heap of stones, under and among which were also found,-

1. Two common arm-rings of bronze.

2. A common neck-ring of the same metal.

3. A brooch with spiral plates.

4. A square plate of thin bronze.

Such is the account of this certainly very remarkable tumulus.

To return now to our waggon. It is clear that this was intended to carry and convey the vase, something in the manner of those dinner-waggons, known to the good old times, when it was thought necessary for the decanters to go round smoothly as well as fast. German archæologists, however, not being called upon to know anything of this now obsolete and therefore antiquarian custom, pronounced waggon, cylinder, and vase, to be parts of a sacrificial instrument of some sort or other, which it is in truth too much the fashion to do with everything whose application to the uses of daily life is not immediately perceived. The most important matter was obviously the waggon, for Roman vases, patellæ, and sieves of bronze are no rarities upon the coasts of the East sea; accordingly, the archæologists of Mecklenburg set themselves to discover, wherever they could, on horns, or monuments, or the like, traces of waggons, in which search, as might be anti- 
cipated, they met with tolerable success, finding in time not only waggons, but even horses and drivers, engraved or carved on various articles of good antiquity; but waggons carrying vases riveted upon cylinders they certainly did not find, and accordingly, for all but themselves the Peccatel bronze remained in all its mystery.

Lisch, however, who had persuaded himself that this bronze vase agreed in character with other bronzes of what he calls the bronze age, and that it resembled in form the clay vessels of the same period, and who besides sees, in all bronze whatever from tumuli, the reliques of a Germanic race, unhesitatingly claimed this for German heathendom. For my part I have never yet seen any bronze of indigenous workmanship repoussé, or resembling this at all in form, till the much later period which Lisch calls the age of iron, and ascribes to the Slavonians; and if I were called upon to seek for an analogon for our vase, I should look for it among Etruscan rather than German bronzes. However, Germanic it was to be; and this theory was taken to have received confirmation from a second discovery made at Frankfort on the Oder in the year 1851-2." (Plate XXVI. fig. 4). This was an implement-for I really cannot call it a waggon-consisting of a hollow tubular handle, ending in a fork, the ends of which turn upwards, and which is fastened upon an axletree arranged so as to carry three wheels, two at the extremities outside the prongs of the fork, and one within these at the middle of the axletree; but for the third wheel the whole thing might remind us of those Etruscan firetongs, also mounted upon wheels, in the British Museum. The wheels themselves are nearly of the same size as those in the museum at Schwerin. The most noticeable peculiarity of this was that on the handle or pole, as Lisch considered it, stood two bronze figures of long-necked and long-beaked birds, one at the opening of the socket, one at the point where the prongs diverge to form a fork. One more such bird stood near the middle of each prong, and the two turned-up ends were likewise surmounted and finished off with larger, but similar, figures of birds, which differed from the others not only in their size, but in having "horns or wings" at the back of their heads. Waggons being uppermost in everybody's thoughts, this three-wheeled instrument was to be one also, although the so-called pole becomes thicker in proportion as it recedes from the axles, and all the birds, with or without horns, are looking in the diametrically opposite direction to that in which the waggon must move. Lisch, and Grimm, acting upon his information, supposing these waggons to be in some way connected with Germanic heathendom, explained them to be symbolical of Woden, the Great Bear, Charles's Wain, and so forth. In

2 Described Meklenb. Archiv. xvi. 261, seq. 
the paper describing this Frankfort implement, mention was made of another such waggon found at Warin in Mecklenburgh, but now, as it appears, lost, ${ }^{\mathrm{a}}$ and to wheels of bronze found at Frisack. I may add, that similar but smaller wheels were found many years ago at Frankfort on the Oder, under what circumstances I do not know, and are now in the National Museum at Berlin.

The birds recalled also to mind a number of similar figures mounted as buttons, or ornaments of dress, which had been dug up at Vietgest, and are now at Schwerin ; ${ }^{\mathrm{b}}$ to which I may add, that several hundreds of the same kind, found at Hohenwalde near Landsberg, in Prussia, may also be seen in the Berlin Museum. Here the matter rested at the close of the year 1852; but from the third number of the Publications of the Historical Society of Styria, for the year 1852, which appeared in 1853, we learned that a still more striking discovery had been made in a barrow at Judenburg, in that province. Among a vast number of various articles of bronze, iron, and gold, the fragments of a bronze waggon had also been found, which, when carefully put together, presented an astonishing object. The car had a flat bottom, 12 inches in length by $7 \frac{1}{4}$ in width. The four wheels were about the same size as those at Schwerin, namely, 5 inches in diameter, with very wide fellies. At each end of the waggon were two heads of animals, with necks much bent, like the letter $\mathbf{S}$, one at each corner. These were assumed to be horses' heads, with very long ears ; but may possibly be only such figures as those at the forked ends of the Frankfort instrument, namely, heads of bulls.

The waggon itself carried a most remarkable group of figures (Plate XXVI. fig. 5). The central one is 9 inches high, female, and entirely naked, save that a sort of girdle goes round the body above the hips (Plate XXVI. fig. 6). It is very slender, and reminds one in many respects of early Etruscan work, such as the Martes and Minervas in the British Museum, which have been so often engraved. The hands are raised to a level with the head, and appear, with this, to have supported some kind of vessel-a plate, bowl, or vase, several of which were in fact found with it. Around this are placed other figures, each about 4 inches high, forming two corresponding groups, one looking towards the one, the other towards the other end of the waggon. Firstly, in the central place of each end, between the heads of horses, or whatever they may be, is the head and body of a stag with lofty antlers, but without legs, standing upon a peg or pin, like the birds of the Frankfort implement. The heads are $2 \frac{1}{2}$, the antlers $3 \frac{1}{2}$ inches high, so that the whole figure of the stag measures 6 inches. On each side of it, and grasping an

a Meklenb. Archiv. xv. 276.

b Mbid. xv. 268. 
antler with one hand, are two human, but sexless, figures (Plate XXVI. fig. 7) ; these complete the front row, which thus consists of five figures in the following order : a horse's or other head; a sexless human figure; a stag; a sexless human figure; a horse's or other head.

The second row at each end, upon the space left between the outer one and the central female figure, is filled also by two human figures, one male, one female, with strongly marked characteristic signs of sex (Plate XXVI. fig. 8). The male holds an axe in one hand which, together with the arm, is uplifted. The whole group is completed by the addition of four figures on horseback, each 5 inches high. They represent men with high caps or helmets, armed with spear and shield, and are placed two and two, on each side of the principal figure, upon the longer sides of the bottom plate, looking towards the contrary ends of the waggon (Plate XXVI. fig. 9). All the female figures have their ears bored, and the remains of earrings: and at the back of the head of each is a loop or ring, to hold similar ornaments.

From the appearance of the patina, the alloy was conjectured to be of a very debased character, that is, to contain a large proportion of lead : subsequent analysis, however, did not bear out this supposition. One portion, upon investigation, gave-

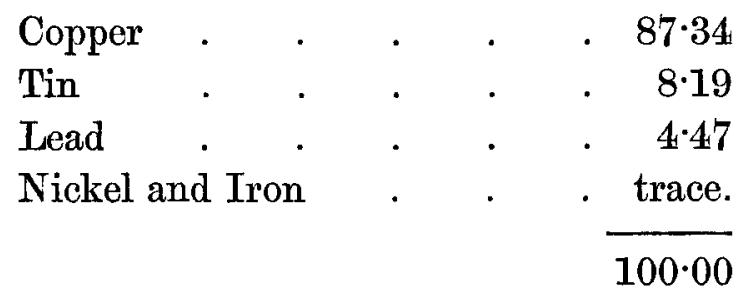

Another was even purer, and seemed to show that the presence of lead, already noticed, was probably accidental :-

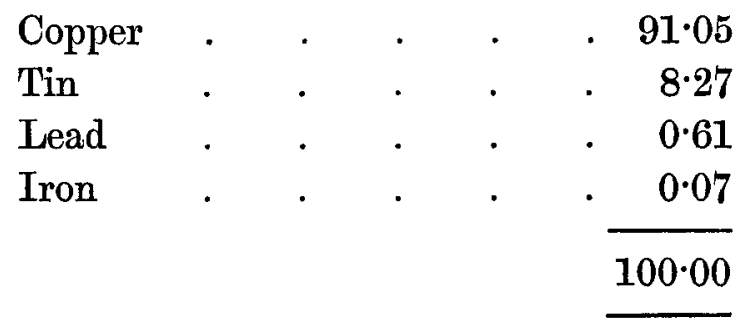

Together with this extraordinary composition, the following objects were found :-

VOL. XXXVI. 
1. An ornamented bronze kelt, with loop and socket, of unusual size, being 11.25 inches long, $2 \cdot 25$ inches broad at the cutting end. The ornament, which consists of fine flutes or ribs, is also unusual (Plate XXVI. fig. 10).

2. A bronze vase apparently intended for suspension by its two twisted handles. The rim was broken off ; round the belly was a band with knobs or bumps, such as we see on very early Italian work. It had a height of 13 inches. Its mouth at present has a diameter of 6.5 inches, and its greatest diameter is 16 inches. It was filled with burnt bones, ashes, and sand, and was therefore a mortuary urn.

3. A second, but much larger vessel or kettle, of the same metal.

4. What is supposed to be the lower part of a helmet, but is unfortunately neither described nor figured. The bronze of which this object consisted had been gilt.

5. Numerous fragments of bronze dishes or bowls, the handles of which are ornamented with rings which jingle at every movement of the vessels.

6. Girdle plates of stamped or repoussé bronze.

7. Fragments of a bronze sieve or colander.

8. Bronze handles, apparently cast upon iron rods, about a finger thick, much in the same way as the bronze is cast upon the feet of the iron chairs discovered at Nineveh.

9. Horses' bits of iron, with bronze ornaments, close to which,

10. A very large bronze kettle.

11. A circular rim of bronze, with raised ornament of spiral work (Plate XXVI. fig. 11).

12. Several bronze rods of twisted work, 25 inches in diameter.

13. Several bronze rings of various sizes, the largest $2 \cdot 5$ inches in diameter.

14. Fragments of very coarse and very fine pottery.

15. A number of amber beads. (Query if not yellow glass?)

16. Two iron spears, each about 18 inches long, iron rods, and what is described as the iron felly of a wheel, but may very likely be the rim of a shield. It is $\cdot 5$ inch thick, and $2 \cdot 3$ inches wide.

17. A spiral gold finger-ring of double wire, about the thickness of a packingneedle, twisted together at the ends and wound spirally. The whole length of the wire is 10.25 inches; also a second ring half melted, and a small cylindrical bead of the same metal.

The reporter, Dr. Robitsch, after giving the long and elaborate account from which these extracts have been made, proceeds upon very meagre grounds to contend for the Slavonic origin of these objects, and during his argument 
mentions incidentally the occurrence of a second similar waggon in a tumulus at Radkersberg, also in Styria. An account of this, as well as other objects discovered with it, and now preserved in the castle of Freudenau, was given by Archivar Dr. Pratobevera in the fourth number of the same Bociety's Transactions.

From this it appears that the find at Radkersberg consisted of -

1. A bronze sword with a solid hilt, of a very unusual form, but still one that approaches some forms found in Gaul, or other parts of the continent. Vide Plate XXVI. fig. 12.

2. Fragments and wheels of one or, perhaps, two waggons, of much the same size as those already mentioned.

3. A circular bronze plate, 45 inches in diameter, with a central hole, and twelve spikes or pegs placed at equal distances round the edge.

4. Two pair of hollow rods of bronze, each pair forming a rectangle. These may possibly have been corners of the waggon-frame.

5. A bronze ring one-third of an inch in thickness, and 1.75 inch in diameter within.

6. A bronze kelt (Plate XXVI. fig. 13) $7 \cdot 25$ inches in length, with a socket and loop, a good deal resembling the kelts found in Magna Grecia, but not those found in France, Germany, or England.

7. A ring with seven spikes placed upon a socketed shaft, with a rivet-hole to secure some kind of handle. The diameter of the ring is 3 inches; the whole length with the socket 6 inches. The opening of the socket itself 1.33 inch.

8. A bronze hair-pin with knob.

9. Five iron spears of different sizes, with sockets for shafts.

10. Fragments of unburnt bones and common rude pottery. The reporter Dr. Pratobevera, in a long and frequently very irrelevant dissertation, annihilates Dr. Robitsch and his Slavonian theory, and contends that these antiquities, as well as those of Judenburg, are of Keltic origin,--that the Gauls, during their settlement in Upper Italy, may have made them in imitation of the Etruscans, and left them behind in Styria, during one of their many migrations into those alpine regions.

So much for waggons and wheels of small size, discovered in several parts of Germany, with adjuncts of interesting character. Before I leave them I will refer, in order to guard against error, to other bronze wheels from Transylvania. A pair of these in Mr. Mayer's admirable museum in Liverpool have a diameter of nearly 2 feet, and a width of felly of $1 \mathrm{inch}$. They can hardly have been actual wheels in use, but probably formed part of some Roman group or ornament from the period when Trajan succeeded in dompting the Dacians.

3 A 2 
The matter of which I treat was destined, however, to become still more complicated and interesting, upon the addition of elements which are as yet unknown in Germany. While engaged in drawing a number of the bronzes in the British Museum, my attention was accidentally called to two very extraordinary groups belonging to Mr. Payne Knight's collection. I will attempt to describe these as well as I can, though they will be best understood from the engraving (Plate XXVII. fig. 1). The first consists of a circular plate of bronze, 10 inches in diameter, surrounded by a rim of the same metal, half an inch in width. This rim is divided at equal distances by ten bronze figures of birds, exactly resembling those upon the Frankfort implement, and ten bronze pomegranates, arranged alternately. The pomegranates are formed of thin bronze, cut out to the necessary form of a cross, and then bent up so as to resemble the calix of a flower, the centre being filled by a large bead of yellow, or of light bluish-green glass, which is fastened to the metal plate below by a wire passing through both. From four points in the lower plate there rise four twisted rods, converging towards the top, and there supporting a second bronze circular plate, five inches in diameter. The foot of each rod is formed by one of the pomegranates already described, and the rod itself is of spirally-twisted wire, increasing in thickness towards the bottom, where the whole rod, as it rests on the bead, has a diameter of about $\cdot 5$ inch. Each rod consists of two separate parts, thus growing thicker towards the base: the lower part is five, the upper four inches long; they are united in the middle by a pomegranate and bead like the rest, and are surmounted by the same where they join the upper plate: the whole is at present kept together by modern wire running within the rods from the upper to the lower surfaces of the two plates. The whole figure, which thus is 10 inches high, now presents the appearance of a pyramid or tent, with four pillars supporting the roof. The area of the base is thus filled: Between the pillars or rods on the north and south sides, close to the rim, are fixed two bronze triangular figures surmounted with rings, cut out of one piece of bronze plate, and decorated with open work and pendent rings. These appear almost to have been handles by which the whole structure might be suspended or carried. Immediately within these, and standing a little across the corners, N.E. N.W. S.E. S.W., are four human figures with very animal faces. Their arms are perfectly semicircular, reaching on one side from the head to the shoulder, on the other, from the shoulder to the hip, so as to form something like a capital $\mathbf{S}$ : in the ears are earrings, and at the back of the head holes to receive similar ornaments. The rings appear to consist always of a system of five, two single ones passing through one another, and the lower supporting three. 

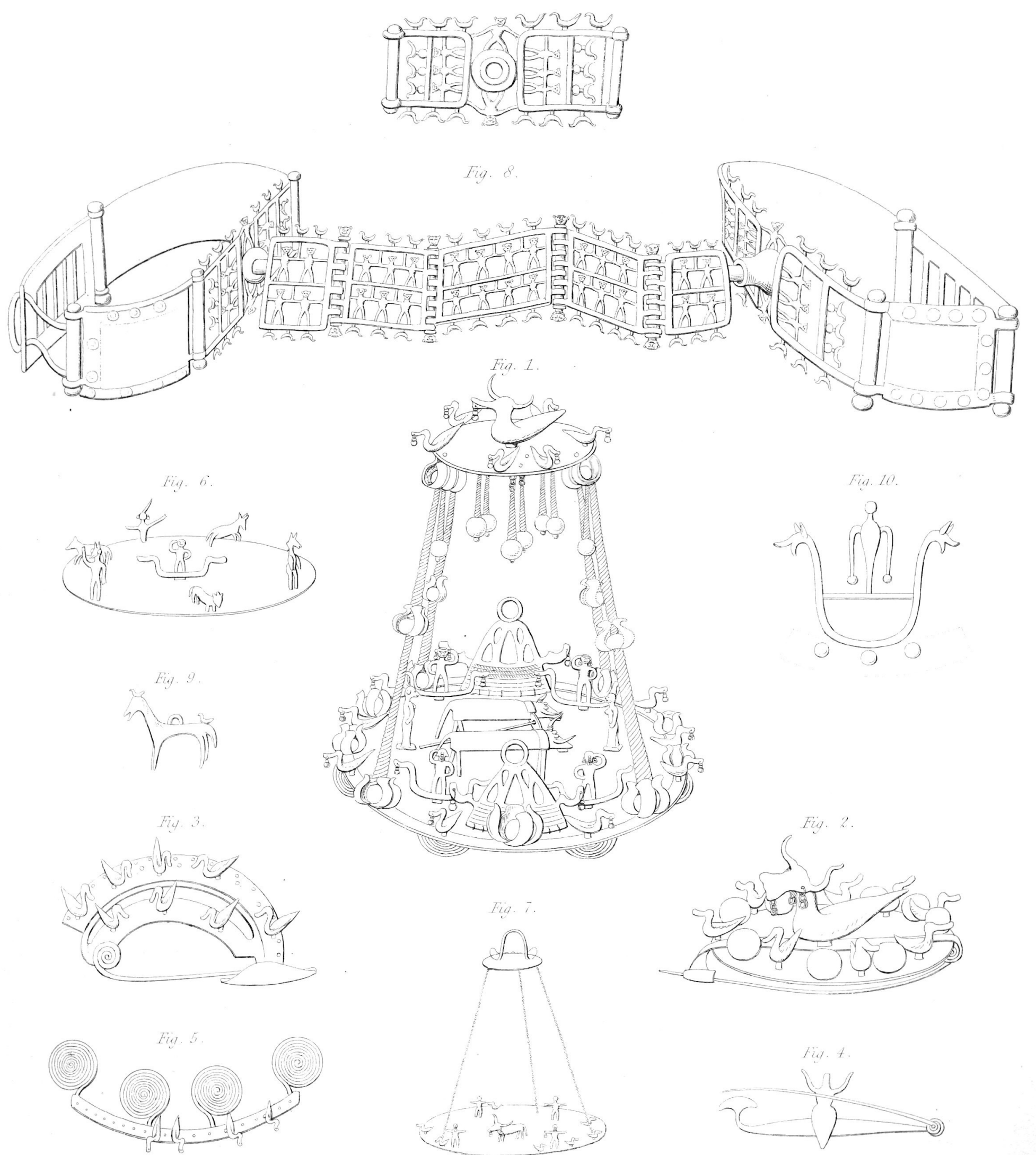

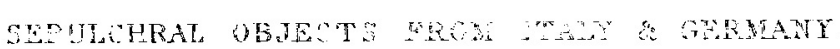


These figures have no signs of sex. They stand upon something for which I find it very difficult to give a name: the object resembles in some respects the Scandinavian figure of ships, with upturned dragonheads, consisting of a straight rod of metal, about two inches long, bent up at each end into a neck and head, like a snake's or perhaps a bird's, and having a hole in the snout from which hang the five rings. The exact centre of the field is filled with a yoke of very rudely-shaped oxen, horned, with the yoke on their necks, and from this runs a long bronze wire between them, which is obviously only a portion of something intended to represent a plough. One horn of each ox is ornamented with torc-like rings close to the head, and from the ears and dewlap there probably depended the system of five rings already described. Behind and before the oxen (in the latter case with the face turned towards them) stands a human figure, with a head of extremely animal character, with large feet, bent arms, and largely developed organs of both sexes, the breasts sharp and prominent, the veretrum of disproportioned size. The upper plate, which forms the roof of the pavilion under which this strange group is collected, is ornamented externally, upon the rim, with six birds similar to those of the lower plate, having long beaks or snouts, from which depend five rings : and in the centre is a similar figure, having horns, exactly like the larger objects in the Frankfort implement, which may perhaps be best described as bird-shaped bodies with bulls' heads, but wingless. From the under side of this roof hang eight pendants, formed in the same manner as the pillars, of twisted wire, and ending in beads of coloured glass, of which one only is blue or green, the rest a pale straw colour. Four of these, which are rather larger than the others, hang at equal intervals from the rim, between the pillars or supports, and have beads at the top also, directly under the plate. The smaller four, which hang rather more under the plate, are without these upper beads.

The second of these compositions, also in Mr. Payne Knight's collection, is in every respect similar to the first, save that the pomegranates upon the lower rim are wanting, the birds, of which there are twenty, not ten, remaining alone, and that the pillars and roof are likewise omitted. Under each bird, which in every case stands not upon legs, but upon a kind of peg or pin, is fixed upon the lower side of the bronze plate a spiral of bronze wire, about 1.5 inch in diameter, exactly resembling the spirals of the North German brooches : these are intended to fasten the birds, whose foot goes through to them. I should have said that this is the case also with the first composition. The dimensions of the several figures are as follows :- 
Men, upon ships, or snakes

Phallic figures

Oxen, from snout to tail

Diam. of spirals at foot

Birds, from snout to tail

Bull on cover
$2 \cdot 5$ inches long, 2 inches high.

$2 \cdot 75$, high.

4.5 ", long, $1 \frac{7}{8}$, high.

$1 \cdot 5 \quad$,

1.5 " long, $\cdot 75$, high.

$\left\{2 \cdot 5\right.$, long, 16 $\frac{6}{8}$, high,

to head, without the horns.

Together with these there were found the following objects of bronze and iron:-

1. A circular bronze plate, similar to that which forms the canopy of the first composition, but a little smaller, being 4 inches instead of 5 inches in diameter, and having ten in lieu of six aquatic birds round the rim, which alternate with ten beads of coloured glass. The centre is occupied by the same composite animal between a bull and bird. Instead of pendants below there is an acus of wire with a twisted spring, by which the whole is converted into a fibula of very unwieldy dimensions (Plate XXVII. fig. 2).

2. A hollow bronze staff, $13 \frac{I}{2}$ inches in length, but apparently broken off at one end. The end which remains is finished in a knob of open or basket work, from which depends a cluster of five rings, such as is described above. This lower part, which may perhaps be called the handle, is cast solid, and ornamented with successive circles, like juxtaposed torcs. The upper part, which is hollow, and seems to have been hammered together, is ornamented with parallel and cross lines, engraved or scratched upon the surface, and very rudely executed.

3. Another hollow staff, 11 inches long, 5 inch diameter, ornamented at each end with torcs, and throughout its length with parallel rows of vandyke scratches. At each end is a loop or ear for the reception of a cluster of rings, the lower of which is still in situ.

4. A large knife, the blade, which is of iron, much decomposed. The handle is similar to that of No. 2, but is thicker, having a maximum width of 1 inch, and 7 inches in length. It ends in a knob of basket-work, to which is appended a bird, from whose beak and tail clusters of rings have been hung. This handle is ornamented with parallel torcs and engraved lines (Plate XXVI. fig. 14).

5. Another, and smaller knife, with a plain handle and iron blade. Mr. Payne Knight states, that all these various objects were taken from a tomb in Campania.

Sir William Hamilton, whose collection was principally made in Italy, possessed 
several articles of the same character, which are now also preserved in the British Museum :-

1. A pair of fibulæ, of semicircular form, about 4.5 inches diameter. They are formed of two concentric flat segments, united by cross pieces at right angles to the chord of the arc, and are about one-third of an inch apart. On the outer one stand five, on the inner three, birds of the kind so often alluded to. The outer rim is also pierced with twelve small holes, at rather irregular distances, which may possibly have been intended for the suspension of chains similar to certain breast ornaments in Professor Bähr's Livonian collection. In this case the rim must have been worn downwards, the beaks of the birds turning upwards. The acus is connected in the usual way with a spiral spring; and both are, in fact, only a continuation of the outer rim or plate upon which the five birds are riveted (Plate XXVII. fig. 3).

2. A bronze fibula (or perhaps a pair), 7 inches long, consisting of a flat strip of bronze, about half an inch wide, ending at one extremity in a spiral wire, with an acus, at the other in a catch, by which the whole is fastened in the usual way. In the centre of the bronze strip is riveted one of the composite figures alluded to, having the body of a bird and the head of an ox with spreading horns. As it at present stands, this figure has been riveted upon the wrong side of the strip of bronze, most likely through the carelessness of a modern restorer (Plate XXVII. fig. 4).

3. A similar figure, probably once forming a part of a similar fibula.

4. A flat strip of bronze, 12 inches long, 1 inch wide, bored at irregular intervals for the reception of twenty-two birds, seven of which still remain in situ.

There are still two or three fibulæ of cognate form in the British Museum, but which cannot be referred exactly either to Mr. Knight's, Sir William Hamilton's, or Mr. Townley's collections.

5. Two other and similar strips, with birds and rivet-holes for some now missing. Upon the longer of these are riveted volutes of wire, vertically disposed, and a little reminding us of the Styrian volutes already noticed. But as it is apparent that this strip has been lined with a new plate, it is uncertain whether the volutes were originally placed as we now see them. It is possible that this piece of bronze may have been the rim or finish of a plate such as Mr. Payne Knight's (Plate XXVII. fig. 5).

6. Among the bronzes of the British Museum, some derived from the collections already noticed, and some from Mr. Townley's, are a large number of extraordinary figures of animals, as rams, oxen, horses, and the like. They have this 
peculiarity, that some, as the bulls, are double-headed, that is, have a head at each end of the body : some have one head at one end, two heads at the other. They have mostly eyelet-holes, by which they would seem to have been suspended; and it is very remarkable that upon the heads and cruppers of several of these animals are diminutive figures of birds (Plate XXVII. fig. 9). A very long, slender human figure, does perhaps not strictly belong to this set; and the same may be the case with the extraordinary group (Plate XXVI. fig. 16) of a man ploughing with two oxen, so disposed that one looks one way, the other in the opposite direction. Indeed both the style and the patina seem to"show that this was at all events not found together with the rest.

An interesting addition to our materials still remains to be noticed. In Dr. Gerhardt's Etruskische Spiegel (Berlin, 1843), vol. i. pl. xviii. and p. 58, we have a long dissertation upon the copy of a mystic cista, the original of which is said to have been in Baron v. Koller's collection, but to have found its way to England. To this cist in general there are grave objections, with which we have at present nothing to do. What is for us most remarkable is, that the cist, which represents a scene of the mysteries, in a very high style of Greek art, should have had in place of a cover, just such a plate as those which I have described (Plate XXVI. fig. 6). The centre is occupied by precisely the same figure as occurs in Mr. Payne Knight's plates, viz. a human form, standing upon the dragon or shipshaped rod, with upturned ends and heads, and having its arms bent into the form of a capital S. This figure Dr. Gerhardt, not knowing anything of ours, erroneously conjectures to be a Hercules. The rim is garnished with rude figures of animals, and men with animal's heads; so that this so-called cover is in fact identical in principle with the compositions which have engaged our attention; and, whatever may be thought of the cista itself, or its connection with the cover, the genuineness of the latter cannot be disputed. It is recorded to have been found in the Basilicata, in the neighbourhood of Naples, and a number of figures of animals, and the like, came together with the copy into the Berlin collection, all of which are said to have been deposited in the cista itself. These are described by Gerhardt as consisting of " seven tolerably human figures, with out-stretched arms, and an eighth with a pointed cap, holding the right hand before the face; two others with indistinct heads of animals; three stags; twenty other quadrupeds, perhaps horses; fourteen pigeons, and eight larger birds, principally joined with small plates, and ringed ornaments;" by which I suppose him to mean the volutes or spirals of wire, and the nose or ear rings which are commonly found with these birds. 
Still more important, however, for us is a composition which he adduces in illustration, from the Borgia collection, and which he calls a scale. It consists of a plate bearing the closest resemblance to Mr. Payne Knight's. In the centre is one ox, with the five rings dependent from the mouth, and one of the ears. There are also four human figures with outstretched arms, with earrings, and rings at the back of the head. Above all, the rim is filled up with figures of birds, riveted down over volutes of spiral wire. The lower plate depends by three chains from a smaller one, which is not ornamented, but is furnished with a sort of handle by which the whole might be carried (Plate XXVII. fig. 7).

I have further to mention that some time ago there was purchased for the British Museum from M. Comarmond of Lyons, a massive bronze object, which he considered might be a pair of panther's collars, with a strong connecting couple. The whole of this consists of open work, produced by combinations of human figures with animal heads, and birds; all of which bear a great resemblance to those which have already engaged our attention. It is not positively known whence this collar originally came; but the choice appears to lie only between France and Italy (Plate XXVII. fig. 8).

It may also be noticed, that some years ago an implement of bronze, ending in a kind of forked hook, was discovered in Ireland. The handle is ornamented with seven figures of birds, placed upon the upper side, as in the case of the forked hook from Frankfort on the Oder, and below each of these is a pendant ring.

Lastly, in the hand of a statue from the well-known archaic tomb at Vulci, is a figure resembling a bird, but with two very large horns of gilt wire.

If now we review all the points of resemblance between these several groups of archæological data, we have the following results, as indicia for the foundation of a theory.

At Peccatel, in Mecklenburg; at Judenburg and Radkersburg, in Styria; at Warin, Frisack, and Frankfort on the Oder, we have waggons, or wheels indicating waggons, upon which something was or might be carried. And we may add, that in that ancient tomb at Vulci were likewise two waggons, with wheels of about the same diameter as those at Judenburg, and with horses' heads and necks at each end, looking opposite ways.

At Frankfort on the Oder we have also wheels attached to an implement which do not appear to be those of a waggon, unless indeed this be construed symbolically, as the circles on Gaulish coins are the representatives of chariots.

At Peccatel, as at Judenburgh, the waggons were accompanied by bronze bowls VOL. XXXVI. 3 B 
or vases, and by bronze kelts of unusual forms. At Judenburg the waggon was surmounted by a group of figures of unusual but very marked forms, and in a recognizable style of art.

In the Payne Knight collection are two circular plates, surmounted with figures in a similar style of art. The identity of treatment in the suspension of ear-rings and hair-rings to these figures is particularly observable.

Some of these figures, namely, those of birds, and oxen with the bodies of birds, are the same as those which have been shown to be placed upon the so-called waggon from Frankfort on the Oder: the same birds have been found at Vietgest in Mecklenburg, and in great numbers near Landsberg in Prussia. They are identical with others upon fibulæ in Sir William Hamilton's collection, which were no doubt obtained in Italy, and probably in Naples, and others still upon a plate given out as the cover to a cist possessed by Baron v. Koller, and what Gerhardt calls a "scale" in the Borgia collection, which last two were certainly found in the neighbourhood of that city.

There is a possibility that similar bulls' heads ornament the corners of the Judenburg waggon; but it is nevertheless possible that these may be, as the Styrian savans state, heads of horses. If this be so, they answer to the horses' heads which decorate the opposite ends of the waggons found in the antique and perhaps pre-Etruscan tomb at Vulci, in which the traces of Assyrian, as well as Egyptian, influence are singularly prominent.

With the Peccatel waggon were deposited a kelt and a sword of bronze; so also with that at Radkersburg; and a bronze kelt was also found, together with the waggon, at Judenburg. None of these are of the forms or types usual in Germany, in the British Islands, or in Scandinavia; but some of them resemble types found in Gaul, in Greece, and in Italy.

At Radkersburg and Judenburg there further occurred, together with the bronze kelts and sword, spear-heads and other articles of iron. The Payne Knight bronzes were also accompanied by knives with iron blades, which were set in handles ornamented with the same figures of birds as those at Frankfort, on the Borgia scale, and with the same combinations of rings as that at Judenburg.

Birds and men, with heads of animals, appear on the couples purchased from M. Comarmond. Birds upon the Irish hook, and a bird with spreading horns like those of an ox decorates the hand of an archaic figure at Vulci.

This is a summing up of our data, and from it it is clear that there are several (strangely complicated) points of resemblance between some or all of those objects from so many different localities, and that there is a probability of their having 
some connection with one another, whatever this may be. I give you the elements

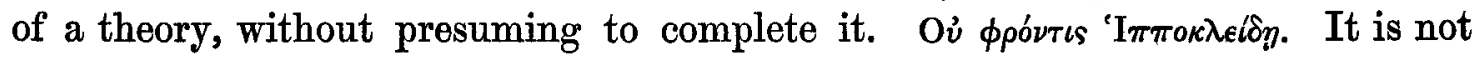
my business. It is no Teutonic matter.

Mr. Payne Knight was of opinion that his plates were connected with some ancient form of religion in Upper Italy, and intentional imitations of a rude and archaic style of art. He says, "From the place where they were found it is probable that they were of Oscan or Campanian work, though no conclusion can be drawn from the style concerning either the age or the country in which they were produced; both the design and execution being affectedly rude and barbarous, evidently intended to imitate the first feeble attempts of savages in their carvings in wood. It is probable, however, from the blades of the sacrificing knives being of iron, that they are not of very remote antiquity, all very ancient utensils of this kind being of brass, hardened by a mixture of tin, which produces a metal inferior only to good steel." He then adds: "This curious set of mystical and symbolical instruments was found in a tomb in Campania, not far from - in the year —." These blanks in his MS. are to be regretted. I suppose the objects really were found in Italy; but whether in the north or the south we cannot unhappily decide; and yet it is rather important that we should. If these things were found in the north, they must have been tolerably spread over all Italy, for they are certainly found in the extreme south; and that they were found in the north is in so far probable, that something very like them has been found in Styria. But even Payne Knight, whom I suppose to have had dim visions of Atellan games and Ambarvalia, was drawn to the south and to Sicily; for he cites Diodorus (merely in the margin), who really is his authority for the notion that these things were not original-in spirit I mean-but affectations of archaism.

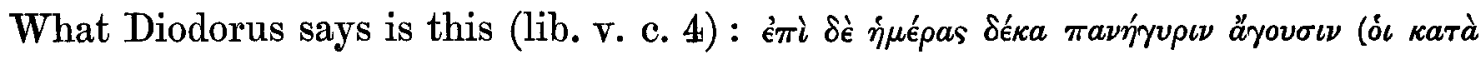

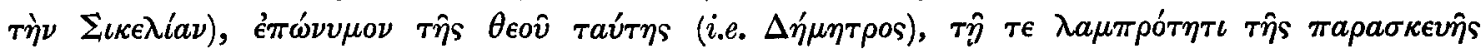

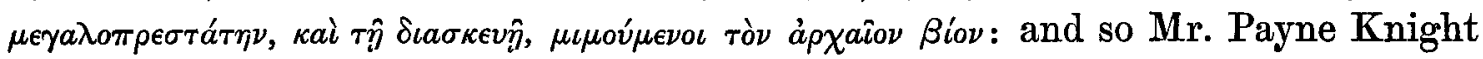
thinks his figures may have been connected with rites of Ceres or Bacchus.

And now what are we say to those various objects, or to what people shall we refer them? Are they Teutonic, as Lisch fancies, and has half persuaded Jacob Grimm to fancy? I cannot think so. They have not made their appearance on any one locality which can be exclusively and distinctly called Teutonic; for, after all, if the Slavish-Obotritic Mecklenburgh were to be admitted to that claim, it is only one set of waggon-wheels that can come under consideration, and these may have only an accidental bearing upon the other features of the case; while, on the other hand, waggons are found in the most ancient tomb of Italy, and the vase 3 в 2 
attached to the Mecklenburgh find is much more Etruscan than German Again I protest, totis viribus, against the doctrine of my friend Lisch, to whose energy and skill we owe a great deal, but who sees Germanic graves in all conical barrows which contain weapons of bronze. This I am perfectly certain is an error-an error, too, that a classical scholar ought never to have fallen into ; and I repudiate, therefore, in limine, any argument that rests upon this most unsure foundation, this unhappy tendency to compliment a nook of Germany at the expense of European history; and with this I necessarily reject the explanation which Lisch and Grimm have given of the waggon and the birds, which sets out with the assumption that the implement found at Frankfort is a waggon, and that this, as well as the Peccatel find, is Germanic. That the "seven stars" are, on the one hand, properly referred to Woden's Wain, Karl's, or Charles's Wain, is true, and that the same seven stars are here and there symbolized by the "hen and chickens," is so also; but this helps us little. We have only four wheels at Peccatel, with a vase that is rather Italian than German; and we have two waggons with four wheels at Vulci. How many there were at Warin, or Frisack, or in the first set noticed at Frankfort on the Oder, we do not know ; nor do we learn what more than wheels was found; nor do we know that the three wheels and the six birds found at Frankfort on the Oder have anything to do with a waggon at all. Again, the birds found at Vietgest and in the Hohenwalde were not reckoned by six or by seven, but by hundreds, and they were obviously ornaments for the dress, to be put on like buttons with shanks; so that here any reference to the six or seven stars of Woden's Waggon is quite out of the question. Moreover, something nearly resembling these forms is found in Italy, and, upon the supposition of their being Teutonic, they must have been brought to Italy during some one of the Teutonic invasions of that country. But then we should expect to find the same things in the lands from which the invaders marched, which is not the case, and we should require to find a reasonable explanation of them in what we know of the feelings and religion of those who took them; but this explanation we cannot give. So that I can only conclude the Germanic populations have nothing to do with the matter.

Must we then attribute them to the Slavonians?

The argument from the locus in quo would no doubt, in this case, have a better foundation, inasmuch as Slavonians have undoubtedly at some period been settled in Mecklenburgh, in the Middle Mark, in Silesia, and in Styria. But it would not apply well to Vulci, to a Campanian tomb, or to the Basilicata by Naples; nor to France, supposing the so-called panther-collars to come from that country; 
nor to Ireland, supposing the Irish hook with the birds to have anything to do with the matter. I am not very learned in the nature and attributes of the Slavonic gods, although I have no doubt some of them are car-borne, like some among the Teutons and the Latins. But it must be supposed, that when Dr. Robitsch claimed the Styrian waggon for a Slavonic goddess he made as good a case out as he could; and, as we must concur with Dr. Pratobevera in opinion that it is a very weak case indeed, the Slavonian hypothesis does not appear well founded, on this side. It may be noticed en passant that the spiral ornaments or volutes made by twisting fine wire, and forming brooches and the like, are very widely dispersed throughout lands which have been held by Slavonic populations; and that ornaments of a similar character, particularly the continued or double spiral, are often found upon implements of bronze, which it was intended to enrich with engraved work. This is not at all a prevalent mode of ornament in purely Teutonic art of an early date: on the other hand, it is very far from uncommon upon weapons and jewels which appear to belong to France, is by no means unexampled in Italy, and is even found in Thrace and Macedon; nay, spirals exactly resembling those of the North Germans and Slavonians, are a main element in the frieze of the so-called tomb of Agamemnon at Mycenæ. So that if, on the one hand, this form is supposed to furnish something of a presumption in favour of a Slavonic hypothesis, on the other it might be cited in support of a Gaulish or even a Greek one.

But, on other grounds, a Gaulish hypothesis must also be admitted. It is very clear that this would in fact explain the Italian, French, and Irish objects: it would also apply to Styria, inasmuch as the migrations of Gauls into the Styrian Alps are abundantly matter of history. But it would leave a difficulty in the Mecklenburg and Frankfort cases, which could not be readily overcome. Moreover, it would be required to show, that anything in Gaulish art resembled, or anything in the Gaulish religion had reference to, the forms of the objects described. Of this at present we know far too little to assert anything with certainty. It is true that, among the sculptured figures of Gaulish gods in Paris, there is one symbolised by an ox and three cranes, who is named Tarvos Trigaranus. The figure may be seen in Montfaucon, vol. ii. p. 424, and in the third vol. of the Academie des Inscriptions, of the year 1717 ; and from Mr. Davies's Mythology of the British Druids (pp. 132, 161) it appears that Tarw Trigaran is Welsh for a bull with three cranes, as indeed it is very nearly Greek for it. All this may possibly be true; but still I am afraid it will not be enough to explain our cows or oxen yoked in a plough, not with three cranes, on their backs, but with ten or 
twenty birds, more like ducks or geese, standing about them. Unless, indeed, upon those sane and singularly reliable principles of Helio-arkite interpretation, by which everything can be shown to be nothing, and nothing to be anything else, the yoke of oxen should symbolise Noah as a husbandman, and other figures therewith connected some other prominent details of his somewhat remarkable history. No doubt a capital Helio-arkite demonstration has been made upon weaker grounds before now.

But it is just possible, after all, that Mr. Payne Knight was right; that the whole affair may be early Italian, and connected in some way with the, to us unknown, ceremonies of the agricultural gods: in which case the resemblance between his bronzes and some of the other objects heretofore mentioned may be merely fortuitous. But all is not, and cannot be so. There is an undeniable resemblance between the strange figures upon the Styrian waggon, and those of Mr. Payne Knight's, Sir William Hamilton's, Baron v. Koller's, and Borgia's bronzes, which is beyond mere accident. The whole of them bear also some likeness to early Etruscan forms, as well as to a number of nondescript figures which have been discovered in various parts of Italy. Among these may be noticed one given by Caylus, vol. i.; the Punic idols in Sardinia, described by Della Marmora, in the Bulletino del Inst. p. 68, a. 1834; the human figures with snake-like arms and legs, noticed by Bonghi, Bullet. 1830, p. 11 : with all which may be compared what Gerhardt says in his Etrusk. Spiegel. Tables XII. XIII. And I would also refer to the handles of a large bronze vessel in the British Museum which is certainly from Italy, and seems to me to be of Etruscan origin. The upper part of these is formed by what resembles a rude human figure, placed upon the same sort of shape as the figures in Payne Knight's and Koller's bronzes with two heads, which are, perhaps, those of dragons. Possibly these may be considered to have some bearing upon this subject (vide Plate XXVII. fig. 10). Nor is it without importance that Etruscans, when pressed by the Gauls, migrated into the Rhætian Alps, from which such implements, if Etruscan, might easily find their way into Styria, and where other objects have been found, bearing evidence of Etruscan origin, as for instance the helmets with inscriptions said to be Etruscan, which were found not far from Radkersberg in the year 1812. (Vide Michali, Mon. Med. p. 331, seq.).

I do not know whether any of our own Archæologists who have bestowed particular attention upon Italian antiquities will be able to give a satisfactory

a Livy, v. 33. Pliny, N. H. iii. 24. Justin. xx. 5. 
account of the forms which I have now the honour to bring to their notice: and especially whether it will be possible to prove the connection of these with any archaic rites of the goddesses Panda and Anna Parenna, or the rural celebrations of the Ambarvalia, or other agricultural ceremonies. But, as I perceive that the whole question must be beset with difficulties, since such accomplished inquirers as Mr. Payne Knight was, and Dr. Gerhardt is, have been unable to give a satisfactory explanation of those parts of it which fell under their observation, it has occurred to me that it was desirable to call the attention of the Society of Antiquaries to it.

I am not without hope that, if these strange things were better known in Europe, some of the gentlemen at the head of the magnificent collections in Paris might be able to give us further light upon the subject, from discoveries either in their own country, or Italy. And it is much to be desired, that it should be brought to the notice of the accomplished Archæologists of the lastnamed land, who have better opportunities than any of us of judging whether there may not yet be many examples extant similar to those I have considered, but which, from the very rudeness of their execution, have hitherto appeared unworthy of being made known. At all events, this paper, while it professes not even to attempt their explanation, will serve to put upon record the existence in various parts of Europe of objects of very unusual forms, which all seem more or less to belong to one another; but which, from being hitherto known only within narrow and unconnected circles of inquirers, have been deprived of that combined illustration which their interesting character deserves, and by which alone their secret has a chance of being read. The key to them all seems, however, to lie in the collections of the British Museum, and thus especially belongs to the competency of the Royal Society of Antiquaries of England.

Postscript.-Since these remarks were written, a remarkable discovery has been made in the neighbourhood of Bologna, which fully confirms the impression that the Payne Knight, Townley, and Koller bronzes are of Etruscan origin. (Vide Relazione d'un Sepulcreto Etrusco, scoperto presso Bologna, by Conte Gozzadini, \&c.) 